\title{
Uji Daya Hambat Ekstrak Spons Laut Callyspongia aerizusa terhadap Pertumbuhan Bakteri Shigella dan Staphylococcus epidermidis
}

\author{
${ }^{1}$ Tifany T. Korompis \\ ${ }^{2}$ Christi D. Mambo \\ ${ }^{3}$ Edward Nangoy
}

\begin{abstract}
${ }^{1}$ Program Studi Pendidikan Dokter Fakultas Kedokteran Universitas Sam Ratulangi Manado
${ }^{2}$ Bagian Farmakologi dan Terapi Fakultas Kedokteran Universitas Sam Ratulangi Manado Email: korompistifany@gmail.com
\end{abstract}

\begin{abstract}
Callyspongia sp. is a kind of marine sponges that produces secondary metabolites, such as steroids, alkaloids, flavonoids, and terpenoids which can be used as antibacterial agents. This study was aimed to determine the inhibition activity of Callyspongia aerizusa marine sponge extract against the growth of Shigella and Staphylococcus epidermidis bacteria. This was an experimental laboratory study. Inhibition activity was tested by using the modified Kirby-Bauer method. The inhibition zones formed by the marine sponge extract were measured. The results showed that the inhibition zones of marine sponge extract against Shigella bacteria was $6.1 \mathrm{~mm}$ and against Staphylococcus epidermidis bacteria was $6.6 \mathrm{~mm}$. Conclusion: Callyspongia aerizusa extract had moderate inhibition activity against the growth of Shigella and Staphylococcus epidermidis bacteria.
\end{abstract}

Keywords: inhibition test, Callyspongia aerizusa, Shigella, Staphylococcus epidermidis

\begin{abstract}
Abstrak: Callyspongia sp. merupakan salah satu jenis spons laut yang menghasilkan metabolit sekunder berupa steroid, alkaloid, flavonoid, dan terpenoid yang bisa dimanfaatkan sebagai bahan antibakteri. Penelitian ini bertujuan untuk mengetahui ada tidaknya daya hambat dari ekstrak spons laut Callyspongia aerizusa terhadap pertumbuhan bakteri Shigella dan Staphylococcus epidermidis. Jenis penelitian ialah eksperimental laboratorik. Uji daya hambat dengan metode Kirby-Bauer yang dimodifikasi menggunakan sumuran untuk mengukur zona hambat yang terbentuk oleh ekstrak spons laut Callyspongia aerizusa. Hasil penelitian mendapatkan zona hambat yang terbentuk pada bakteri Shigella sebesar 6,1 mm dan pada bakteri Staphylococcus epidermidis sebesar 6,6 mm. Simpulan: Ekstrak spons laut Callyspongia aerizusa memiliki daya hambat sedang terhadap pertumbuhan bakteri Shigella dan Staphylococcus epidermidis.
\end{abstract}

Kata kunci: uji daya hambat, Callyspongia aerizusa, Shigella, Staphylococcus epidermidis

Indonesia merupakan negara dengan wilayah lautan yang luas dengan segala keragaman biota laut. Hal ini menjadikan Indnesia sebagai negara yang sangat prospektif untuk mengembangkan bahan asal lautnya. ${ }^{1}$ Indonesia sebagai negara dengan keanekaragaman hayati laut yang besar dapat memanfaatkan kekayaan bahari tersebut untuk diteliti dan dikembangkan sebagai bahan dasar obat. Di Sulawesi utara tercatat bahwa $1,33 \%$ yang menutupi terumbu karang ialah spons laut. ${ }^{2}$ Spons laut merupakan salah satu komponen biota laut yang menjadi penyusun terumbu karang yang terdapat di perairan Indonesia dengan jumlah 850 spesies. ${ }^{3}$

Spons laut sangat menarik untuk diteliti karena kandungan metabolit sekunder yang dihasilkannya yang berpotensi untuk dikembangkan dalam 
bidang pengobatan. ${ }^{4}$ Callyspongia $s p$. merupakan salah satu jenis spons laut yang menghasilkan metabolit sekunder berupa steroid, alkaloid, flavo-noid, dan terpenoid yang ke depannya dapat dimanfaatkan sebagai bahan baku obat. ${ }^{5}$

Shigella merupakan basil Gram negatif yang menyebabkan penyakit disentri basiler sedangkan Staphylococcus epidermidis merupakan bakteri kokus gram positif yang merupakan penyebab infeksi kulit ringan disertai pembentukan abses. ${ }^{6}$ Pengobatan untuk infeksi yang disebabkan oleh Shigella dapat menekan gejala tetapi belum sepenuhnya memberantas organisme dari saluran cerna. Resistensi obat oleh infeksi yang disebabkan oleh Staphylcoccus epidermidis dilaporkan lebih tinggi terhadap antimikroba dibandingkan dengan infeksi yang disebabkan oleh Staphylococcus yang lain. ${ }^{7}$

Tujuan penelitian ini ialah untuk mengetahui daya hambat ekstrak spons laut Callyspongia aerizusa terhadap pertumbuhan bakteri Shigella dan Staphylococcus epidermidis dengan penilaian zona hambat yang terbentuk.

\section{METODE PENELITIAN}

Jenis penelitian ini ialah eksperimental laboratorik yang dilaksanakan di Laboratorium Farmakognosi dan Fitokimia serta Laboratorium Mikrobiologi Fakultas Matematika dan Ilmu Pengetaahuan Alam Universitas Sam Ratulangi. Penelitian ini dilaksanakan sejak bulan Agustus sampai dengan bulan Novembar 2017. Sampel penelitian ini ialah spons laut Callyspongia aerizusa yang diambil dari perairan Siladen Sulawesi Utara.

Tahap-tahap penelitian ialah sterilisasi alat dan bahan, pembuatan ekstrak spons laut Callyspongia aerizusa, pembuatan media peremajaan, pembuatan suspensi bakteri, dan pengujian bakteri.

Metode yang digunakan dalam penelitian ini ialah metode modifikasi KirbyBauer dengan menggunakan sumuran. Media MHA disediakan sebanyak 6 cawan Petri dengan masing-masing 3 sumur. Tiga cawan Petri untuk bakteri Shigella dan tiga cawan
Petri lainnya untuk bakteri Staphylococcus epider-midis. Enam sumur pertama diisi dengan ekstrak spons laut Callyspongia aerizusa sebagai kelompok intervensi, 6 sumur berikut-nya diisi siprofloksasin sebagai kelompok kontrol positif, dan 6 sumur berikutnya diisi dengan akuades sebagai kontrol negatif. Setiap cawan Petri berisi satu sumur kelompok intervensi, satu sumur kelompok kontrol positif dan satu sumur kelompok kontrol negatif. Cawan Petri selanjutnya diinkubasi selama 24 jam di dalam inkubator dengan suhu $37^{\circ} \mathrm{C}$.

Pengamatan dilakukan setelah cawan Petri diinkubasi selama 24 jam dalam inkubator. Pengamatan dilakukan dengan mengukur zona bening yang terbentuk disekitar sumur. Zona hambat yang terbentuk disekitar sumur diukur diamerter vertikal dan diameter horizontal dengan satuan milimeter (mm) dengan menggunakan jangka sorong. Diameter zona hambat dapat diukur dengan rumus:

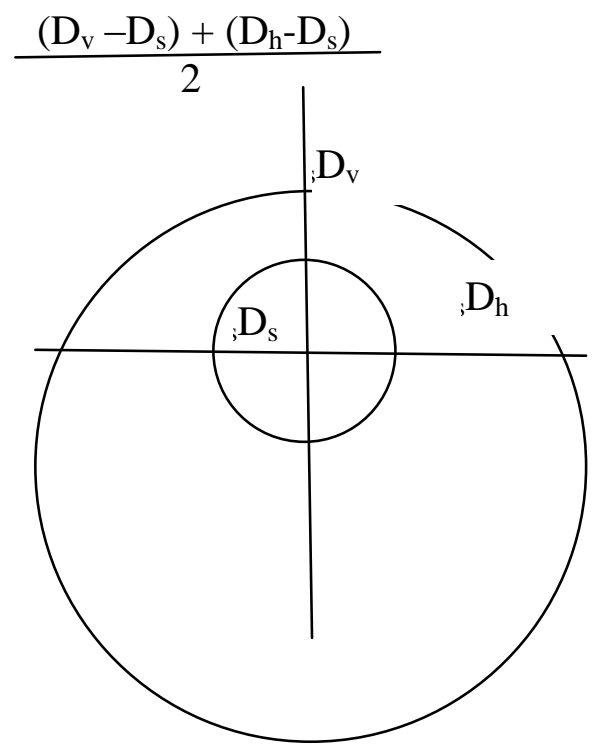

$\mathrm{D}_{\mathrm{s}}$ : Diameter Sumur

$\mathrm{D}_{\mathrm{v}}$ : Diameter vertikal

$\mathrm{D}_{\mathrm{h}}$ : Diameter horizontal

Penilaian zona hambat yang terbentuk menggunakan kategori Davis dan Stout, yang terbagi atas: tidak ada zona hambat; kategori lemah yaitu kurang dari 5mm; kategori sedang yaitu 5-10 $\mathrm{mm}$; kategori kuat yaitu zona hambat 11-20 mm; dan kategori sangat kuat yaitu lebih dari $20 \mathrm{~mm}^{8}$ 


\section{HASIL PENELITIAN}

Pengujian daya hambat dilakukan dengan mengukur zona hambat yang terbentuk di sekitar sumur dengan menghitung diameter vertikal dan horizontal kemudian dimasukkam ke dalam rumus. Pertumbuhan bakteri setelah masa inkubasi terlihat menjauhi sumur, artinya terdapat zona hambat pada sumur yang diberikan ekstrak spons laut Callyspongia aerizusa dan kontrol positif siprofloksasin, tetapi tidak terdapat pembentukan zona hambat pada sumur yang diberikan akuades sebagai kontrol negatif.

Tabel 1 menunjukkan rerata diameter zona hambat yang terbentuk disekitar sumur yang diberikan ekstrak spons laut Callyspongia aerizusa, siprofloksasin, dan akuades.

Tabel 1. Perbandiangan diameter zona hambat yang terbentuk

\begin{tabular}{cccc}
\hline $\begin{array}{c}\text { Cawan } \\
\text { Petri }\end{array}$ & $\begin{array}{c}\text { K- } \\
(\mathbf{m m})\end{array}$ & $\begin{array}{c}\text { K+ } \\
(\mathbf{m m})\end{array}$ & $\begin{array}{c}\mathbf{P} \\
(\mathbf{m m})\end{array}$ \\
\hline A & 0 & 26,5 & 6,1 \\
B & 0 & 23 & 6,6 \\
\hline
\end{tabular}

Keterangan: K-. kontrol negatif; K+. kontrol positif; P. Ekstrak spons laut Callyspongia aerizusa; A. Shigella, B. Staphylococcus epidermidis.

\section{BAHASAN}

Pada penelitian ini, digunakan akuades sebagai kontrol negatif karena merupakan larutan pengencer pada kontrol positif. Akuades sebagai kontrol negatif dapat membuktikan bahwa larutan pengencer tidak memiliki daya hambat. ${ }^{9}$ Siprofloksasin sebagai kontrol positif digunakan untuk membandingkan daya hambat antara obat dan ekstrak spons laut Callyspongia aerizusa, Siprofloksasin merupakan obat yang termasuk dalam golongan florokuino-lon yang memiliki daya antibakteri yang baik terhadap bakteri Gram negatif maupun bakteri gram positif. $^{10}$

Pada penelitian ini didapatkan adanya zona hambat yang terbentuk disekitar sumur yang diberikan ekstrak spons laut Callyspongia aerizusa. Diameter zona hambat yang terbentuk pada daerah sekitar sumur yang diberikan ekstrak spons laut tersebut dapat dijadikan tolak ukur kekuatan senyawa yang terkandung dalam ekstrak spons laut. Semakin lebar diameter zona hambat disekitar sumur, semakin kuat pula senyawa aktif yang menghambat pertum-buhan bakteri. ${ }^{9}$

Rerata zona hambat yang terbentuk yaitu $6,1 \mathrm{~mm}$ pada bakteri Shigella dan 6,6 $\mathrm{mm}$ pada bakteri Staphylococcus epidermidis. Berdasarkan kategori pengukuran zona hambat, ${ }^{8}$ maka ekstrak spons laut Callyspongia aerizusa tergolong dalam daya hambat sedang terhadap pertumbuhan bakteri Shigella dan Staphylococcus epidermidis. Zona hambat yang terbentuk pada sumur yang diberikan ekstrak spons laut Callyspongia aerizusa lebih kecil dibandingkan zona hambat yang terbentuk pada sumur yang diberikan obat siprofloksasin sebagai kontrol positif sedangkan untuk sumur yang diberikan akuades tidak terbentuk zona hambat.

Penelitian mengenai daya hambat dari ekstrak spons laut Callyspongia sp. sudah pernah dilakukan sebelumnya namun dengan bakteri uji yang berbeda. Pada hasil penelitian sebelumnya diketahui bahwa spons laut Callyspongia sp. dapat menghambat pertumbuhan bakteri Staphylococcus aureus, ${ }^{3}$ Klebsiella pneumonia, Staphylococcus aureus, Eschericia coli, dan Salmonella typhi. ${ }^{11}$

Hambatan pertumbuhan terhadap bakteri Staphylococcus aureus menunjukkan kekuatan zat aktif yang terkandung dalam ekstrak spons laut Callyspongia $s p$. Zat aktif yang dimaksud yaitu steroid, alkaloid, flavonoid, dan terpenoid. ${ }^{12,13}$ Mekanisme kerja steroid sebagai antibakteri berhubungan dengan membran lipid dan sensitivitas terhadap komponen steroid yang menyebabkan kebocoran pada lisosom. Steroid dapat berinteraksi dengan membran fosfolipid sel yang bersifat permeabel terha-dap senyawa lipofilik sehingga menyebab-kan integritas membran menurun serta morfologi membran berubah yang menyebabkan sel rapuh dan lisis. ${ }^{14}$ Alkaloid dapat merusak 
komponen penyusun peptidoglikan pada sel bakteri sehingga lapisan dinding tidak terbentuk secara utuh. ${ }^{3}$

Mekanisme kerja flavonoid sebagai antibakteri dapat dibagi menjadi tiga yaitu menghambat sintesis asam nukleat, fungsi membran sel, dan metabolisme energi. ${ }^{15} \mathrm{Di}$ dalam flavonoid juga mengandung senyawa fenol yang merupakan suatu alkohol yang bersifat asam. Fenol memiliki kemampuan untuk mendenaturasi protein dan merusak membran sel. ${ }^{16}$

Mekanisme kerja terpenoid sebagai antibakteri adalah saat berinteraksi dengan membran luar dinding sel bakteri mengakibatkan membran luar dinding sel bakteri tersebut rusak. Rusaknya membran luar dinding sel yang merupakan pintu keluar masuknya senyawa akan mengurangi permeabilitas dinding sel bakteri yang mengakkibatkan sel kekurangan nutrisi, sehingga pertumbuhan bakteri terhambat atau bahkan mati. ${ }^{17}$

\section{SIMPULAN}

Berdasarkan hasil penelitian dapat disimpulkan bahwa ekstrak spons laut Callyspongia aerizusa mempunyai daya hambat sedang terhadap pertumbuhan bakteri Shigella dan Staphylococcus epidermidis.

\section{SARAN}

Untuk penelitian selanjutnya disarankan untuk melakukan pengamatan lebih dari satu kali untuk menilai kekuatan daya hambat dari ekstrak spons laut Callyspongia aerizusa.

\section{DAFTAR PUSTAKA}

1. Suriani, Usman H, Ahmad A. Isolasi, karakterisasi, dan uji bioaktivitas metabolit sekunder dari spons Callyspongia sp. Marina Chimica Acta. 2012;12:2-7.

2. Suraji, Rasyid N, Kenyo AS, et al. Profil Kawasan Konservasi Provinsi Sulawesi Utara. 2015; p.6.

3. Warbung YY, Wowor VNS, Posangi J. Daya Hambat Ekstrak Spons Laut Callyspongia sp. terhadap Pertumbuhan Bakteri Staphyllococcus aureus. 2013.
4. Hanani E, Mum'im A, Sekarini R, dan Wiryowodagdo S. Uji Aktivitas Antioksidan Beberapa Spons dari Kepulauan Seribu. 2006;6:1.

5. Manggalea FP, Posangi J, Wowor MP, dan Bara R. Uji Efek Antibakteri Jamur Endosimbion Spons Laut terhadap bakteri Pseudomonas aeruginosa dan Escherica coli. eBm. 2015;3:377.

6. Syahrurachman A, Chatim A, Soebandrio A, Karuniawati A, Santoso A, Harun B, et al, editors. Buku Ajar Mikrobiologi Kedokteran (Edisi revisi). Jakarta: Binarupa Aksara. 2010; p.1345,198-9

7. Brooks GF, Carrol KC, Butel JA, Morse AS, Mietzner AT. Mikrobiologi Kedokteran Jawetz, Melnick, dan Adelberg (25th ed). Jakarta: EGC, 2010; p.193-95,134.

8. Repi NB, Mambo C, Wuisan J. Uji efek antibakteri ekstrak kulit kayu manis (Cinnamomum burmanii) terhadap Escherichia coli dan Streptococcus pyogenes. eBm. 2016; 4:2.

9. Kaharap AD, Mambo C, Nangoy E. Uji efek antibakteri ekstrak batang akar kuning (Arcangelisia flava Merr.) terhadap bakteri Staphylococcus aureus dan Eschericia coli. 2016;4:3.

10. Syarif A, Estuningtyas A, Setiawati A, Muchtar A, Azalia A, et al, editors. Farmakologi dan Terapi (5th ed). Jakarta: Gaya Baru, 2007; p. 585-7.

11. Rachana MRS, Lipton AP, Thankamani. Antibacterial and antifouling activity of the marine sponge Callyspongia diffusa collected from south-west coast India. Int J Biotechnol Biochem. 2016;12:36.

12. Krisyuninda, Puspita M. Uji toksisitas fraksi spons Callyspongia sp. dengan metode brine shrimp test (BST) dari perairan pasir putih Situbondo. Surabaya: Institut Teknologi Sepuluh Nopember; 2012.

13. Sari NI, Ahmad A, Dali S. Isolasi dan karakterisasi protein bioaktif dari spons Callyspongia sp. sebagai zat antioksidan. Makassar: Program Sarjana Universitas Haanuddin; 2014. Available from: URI: http://repository.unhas.ac.id/handle/123 456789/8695.

14. Bontjura S, Waworuntu OA, Siagian KV. Uji efek antibakteri ekstrak daun leilem 
(Cleodendrum minahassae l.) terhadap bakteri Streptococcus mutans. Pharmacon. 2015;4;98-9.

15. Cushnie TPT, Lamb AJ. Antimicrobial activity of flavonoids. Int $\mathrm{J}$ Antimicrobial agents. 2005;26:343-56.

16. Polakitan IR, Fatimawali, Leman MA. Uji daya hambat ekstrak daun sembung rambat (Mikania micrantha) terhadap pertumbuhan Steptococcus mutans.
Pharmacon. 2017;6:7

17. Rachmawati F. CN Maulita, Sumantri. Uji aktivitas antibakteri fraksi kloroform ekstrak etanol pegagan (Cantella asiatica (L) Urb) serta identifikasi senyawa aktifnya. Excteam. 2011. Available from: https://www. excteam.id/file/0B08deWFYnj7uc2FU TkhvN3JJR0k. 
Korompis, Mambo, Nangoy: Uji daya hambat ekstrak spons laut ... 